УДК 37

DOI $10.21661 / \mathrm{r}-116220$

\title{
Н.В. Дегтярева
}

\section{ЗНАЧЕНИЕ МЕТАПРЕДМЕТНОГО СОДЕРЖАНИЯ ОБРАЗОВАНИЯ В ФОРМИРОВАНИИ ПРОФЕССИОНАЛЬНЫХ КОМПЕТЕНЦИЙ}

Аннотация: в статье рассматриваются возможности метапредметного содержания образования в преподавании дисциплин высшей школь на примере товароведения. В работе представлено определение понятия «фундаментальные образовательные объекты», а также выделены способы отыскивания фундаментальных образовательных объектов в различных учебных областях.

Ключевые слова: метапредмет, метапредметное содержание образования, личностно-ориентированное обучение, товароведение, фундаментальные образовательные объекты.

\section{N.V. Degtyareva}

\section{THE ROLE OF METASUBJECT CONTENT OF EDUCATION IN PROFESSIONAL COMPETENCY FORMATION}

Abstract: the article describes the opportunities of metasubject content in subject teaching of higher education and the merchandizing is shown as an example. It also gives an explanation to the "fundamental educational subjects" concept and emphasizes the ways of searching the fundamental educational subjects in different educational areas.

Keywords: metasubject, metasubject content of education, person-oriented education, merchandizing, fundamental educational subjects.

Современную функциональную систему современной образовательной деятельности мы рассматриваем с позиций личностно-ориентированного обучения, основными элементами которого являются: потребность и мотивы образовательной деятельности; внешние и внутренние цели; программы деятельности; принятие решений как результат самоопределения студента; продукты деятель- 
ности; деятельностно важные личностные качества; внешняя среда и информационная основа для образовательной деятельности, которую составляют фундаментальные образовательные объекты, специально отбираемая информация, необходимые пособия и материалы.

Рассмотрим подробнее значение фундаментальных образовательных объектов (или метапредмета) в товароведческой подготовке студентов. Под фундаментальными образовательными объектами понимаются ключевые сущности, отражающие единство мира и концентрирующие в себе реальность познаваемого бытия, узловые точки основных образовательных областей, благодаря которым существует реальная область познания и конструируется идеальная система знаний о ней [1, с. 198].

Существуют способы отыскивания фундаментальных образовательных объектов в различных учебных областях:

1. Анализ науки или исходной деятельности. В соответствующей учебному предмету науке или области деятельности выделяются реальные предметы и явления: например, в товароведении - это товар с его свойствами, классификацией, разновидностями; в ТН ВЭД - совокупность различных признаков товаров, составляющих основу классификации.

2. Анализ учебного предмета. В установленных для высшей школы дисциплинах преподаватель выделяет ключевые методологические элементы, затем отыскивает соответствующие им объекты реальной действительности, которые и переводит на первичные стадии учебного познания студентами. Так, в курсе экспертизы одной из тем является методика определения влажности изделий идеальная конструкция; реальным же образовательным объектом здесь выступает явление испарения влаги, которое ускоряется под воздействием высокой температуры. Поэтому при изучении методики определения влажности важно обратить внимание на процесс испарения влаги, с которым студенты знакомы из школьного курса физики, таким образом, мы имитируем идеальное знание о реальном объекте. 
3. Рефлексивный анализ учебной информации. Фундаментальные образовательные объекты могут быть обнаружены непосредственно в ходе образовательной деятельности. Отыскивание и фиксирование фундаментального образовательного объекта состоит в следующем: преподаватель задает вопрос или формулирует задание, которое предполагает концентрацию усилий в отыскивании главных объектов изучаемой предметной области; результаты поисков фиксируются, анализируются, на их основе коллективно отбираются реально изучаемые объекты.

Основной целью метапредмета «Товары» может быть осознание студентами механизмов товароведения, его законов и взаимосвязей.

Возможные задачи метапредмета: 1. Выяснить, какие условия и факторы привели к необходимости стандартизации товаров, появлению международных, межгосударственных, региональных и государственных систем стандартизации; что привело к созданию специальных условий хранения и транспортирования; зачем потребовалось создавать систему оценки и контроля свойств товаров. 2. Выяснить причины создания классификаций товаров. 3. Разработать систему контрольных, фискальных и правоохранительных процедур в отношении товара.

Метапредмет имеет гибкий характер построения и содержания, возможна его оперативная перекомпоновка, построение на его основе новых метапредметных структур. Безусловно, что содержание, виды деятельности, формы и методы обучения, способы оценки результатов в метапредмете зависят от методического мастерства преподавателя и результатов рефлексивной деятельности студентов. Метапредмет может входить в структуру товароведческой подготовки, иметь статус метапредметной темы или раздела.

Опыт формулирования студентами собственных версий, составления ими культурно-логических и нравственных проблем, столкновение позиций, написание текстов, позволит увидеть в этих работах мысли и идеи, свойственные науке, древним и современным ученым. Создаваемые студентами творческие резуль- 
таты - исторические исследования, имеют не только учебную, но и культурологическую значимость, поскольку способствуют приращению культуры $[1$, c. 202].

Формирование товароведческих понятий в сознании студентов идет от эмпирического уровня, свойственного чувственным знаниям, к углублению в сущность предметов и явлений, к уяснению объективных закономерных связей, объединяющих различные предметы и явления в единую систему. Такая стадия именно и характеризует подлинно понятийный уровень познания. С другой стороны, замечено, что овладение понятийным уровнем мышления обостряет способность человека к чувственному восприятию вещей и явлений.

Эмпирический уровень товароведческих знаний связан с понятиями, отражающими конкретные товары. Но и на этом уровне их формирование идет в определенной системе, которая, собственно, служит основой системы понятий более высокого порядка, таких, как качество, сорт, сертификация продукции.

Например, понятие «хлеб» выражает собой единство разнообразных видов этого продукта. Говорить о том, что студент обладает товароведными знаниями о хлебе, можно только тогда, когда он знает, из чего сделан хлеб, какие бывают его разновидности и чем они друг от друга отличаются, знает то особенное, что различает эти разновидности, делая их единственными в своем роде; знает, что такое «мука», «соль», «дрожжи», «вода» и другие понятия, обозначающие исходные продукты для получения хлеба; знает, как получают хлеб и владеет в этой связи целым рядом других понятий, такими как «зерно», «мукомольное производство», «хлебопечение», «режим выпечки» и др.; объясняет из чего складываются свойства хлеба и какое влияние на них оказывают составляющие компоненты и способы его получения, и на всей этой основе владеет материалом о качестве хлеба и методах его определения, т.е. знает, какие именно свойства характеризуют потребительскую стоимость хлеба как товара, каким требованиям должно отвечать каждое из этих свойств, как выявлять свойства хлеба и устанавливать степень их соответствия нормативному документу [2, с. 47]. 
Именно подобная взаимосвязанная совокупность понятий и есть система. Она означает знание и одновременно выражает конкретность этого знания.

По нашему мнению, метапредметное содержание образования поможет студентам, прежде всего, понять закономерности науки, пройти собственный путь создания культурно-исторических аналогов.

\section{Сиисок литературы}

1. Хуторской А.В. Современная дидактика. - СПб.: Питер, 2001. - 544 с.

2. Лагуткина Н.В. Подготовка студентов к товароведчекской деятельности на основе применения образовательной технологии «Модельное предприятие»: Дис. ... канд. пед. наук: - Караганда, 2004. - 208 с.

Дегтярева Наталья Викторовна - канд. пед. наук, доцент ФГБОУ ВО «Сибирский государственный университет геосистем и технологий», Россия, Новосибирск.

Degtyareva Natalia Viktorovna - candidate of pedagogical sciences, associate professor FSFEI of HE "Siberian State University of Geosystems and Technologies", Russia, Novosibirsk. 